\title{
The Impact of Inter-Ethnic and Religion Relations on Social Change in the City of Manado (A Sociological Study)
}

\author{
Suprijati Sarib ${ }^{1}$, Prilya Mufida Almustaqim ${ }^{2}$, Adriandi Kasim ${ }^{3}$, Zainuddin Soga ${ }^{4}$ \\ \{suprijatisarib95@gmail.com $\left.{ }^{1}\right\}$ \\ IAIN Manado ${ }^{1}$ \\ Universitas Islam Negeri Maulana Malik Ibrahim Malang ${ }^{2}$ \\ IAIN Manado ${ }^{3}$ \\ IAIN Manado ${ }^{4}$
}

\begin{abstract}
This article aims to describe the effects of ethnicity and religion on social change in minority communities. Manado City has ethnics ofMongondow, Minahasa, Sangihe and also external ethnic that have mingled in the life of a multicultural society of Manado. Human beings are born in need of other people. Different needs and interests in seeing or doing something story. Similarly, certain groups have needs and interests different to those of other groups. This is caused by differences in mindset, culture and behavior of individuals and even different religions. The teachings of religion as social binding hence yield the idea that there will be not extreme words of rejection and imitation and tolerance limits between religions, ethnicities in life need to be respected. The research findings bring forward that education, knowledge, attitudes, social interactions influence the origin, ethnicity, religion of A community which has a culture A, move to region B with the same thing. If the person still carries the original culture with a conservative perspective, of course he will not be well received in the new place, and also vice versa. In other words, even if the person has a strong influence, it would be better if he still makes adjustments to the culture of his new residence.
\end{abstract}

Keywords: Social, Ethnic and religious changes, Multicultural, Manado city

\section{Introduction}

Man created by Allah the Almighty as a caliph on the earth, as what the Lord said in the Qur'an surah Al-Baqarah:30. [1] Philosophically, to confirm its role as caliph on earth, humans carry out five kinds of relations, namely: (1) relations with Allah, (2) relations with oneself, (3) relations with fellow humans, (4) relations with nature and (5) relations with the unseen realms. The relationships that are lived by humans are manifestations carrying out the mandate of human caliphate on earth. The relationship with fellow human beings is absolutely necessary. According to Ismail al-Faruqi, humanity is the object of human moral action. Relationship with fellow human beings can manifest sillaturrahmi, as the word of Allah the Almighty in Surah An-Nisa:1 [1]. The 
presentation of this verse provides an understanding that if humans make a positive relationship, then the relationships with fellow humans will become closer, thus supporting each other for personal development. Conversely, if humans harm the relationships witheach others, the relationship between humans will be intrinsically distal, and what exists is mutual jealousy, envy, hatred, hostility and quarrels.

The development of life requires integration between physical growth and spiritual growth as well as relationships between human beings. This includes the relationship both between individuals and groups who are always aware of the differences amongst themselves. Thus, each individual must always maintain their relationship with other humans, so that social change can be carried out positively in the community. This is in accordance with the Word of Allah in surah AlHujurat verse: 13 , stating that humans are originally born as individuals, and then they live in groups that start from family environment. This environment then develops into a wider social group, namely the surrounding community and human society in general. As such, the lives of individuals in society are formed, creating both homogeneous and heterogeneous.

In a narrow sense, society is a group of people limited by certain aspects such as territories, nations, groups and so on. Given this concept of social classification, people then develop into a number of groups, such as Manado, Javanese, Gorontalo, and so on. In the broadest sense, what is meant by society is the overall relations in living together not limited by environment, national boundary and others. In the same vein, the entirety of all relationships in community life is also part of this wide relationship. The society represents a whole (sitas complex) of parts that form a unit [2].

As Indonesian society is a pluralistic society in terms of ethnicity, ethnicity, and religion. For that, humans cannot live in only one tribe, one religion or one group, because humans cannot live alone. That is why they live in groups that are either small or big groups. These include tribes that are remote and large groups like those in modern countries. This is in line with the conditions of humanity. Humans, according to their nature, cannot live independently, meaning that humans can live perfectly if they live in groups involved in a society. In other words, humans are social beings because they need one another[3].

Ethnic diversity and religious differences in the city of Manado can affect social interaction, which results in social changes characterized by differences in stance and feelings. This difference gives rise to competition and result in prolonged clashes as well as conflicts between them, both in social life and life others.

\section{Method}

The research problems under investigation include the following: 1) What are the influential factors to the association between ethnicity and religion on social change in Manado community; 2) The extent to which these factors influence social change in Manado. The research objectives include: 1) to find out and identify the factors that influence inter-ethnic and religious relations to social change in Manado community; 2) To analyze the extent to which these factors influence social change in the community in Manado City. Data collection techniques operative were observation, interview, and documentation techniques. Data sources in this study were primary data and secondary data. The population and sample can be represented by 3 (three) sub-districts, each in Tuminting district, Wenangdistrict and Paaldistrict. From each sub-district, the sample 
were taken purposively from two villages. From each village, 30 ethnics and 30 religions were chosen randomly, so the total number of samples was 60 . The study employed a descriptive survey approach [3]. Data analysis applied quantitative analysis by using numbers and described by words arranged into expanded text by reading the percentage proportion of data based on the answers garnered using simple quantitative frequency distribution analysis. The data analysis technique was simple tabulation. The collected data were tabulated and analyzed by percentage with simple tabulations, which were grouped based on factors that influenced the religious behavior of the people in the city of Manado.

The simple tabulation method with the percentage used as an analysis parameter according to Nazir is as follows:

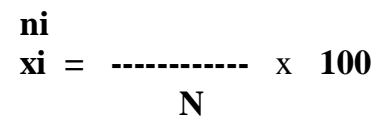

Let:

$\mathrm{xi}=$ the percentage in the $\mathrm{i}^{\text {th }}$ group

ni $=$ the number of respondents in the $i^{\text {th }}$ group

$\mathrm{N}=$ the total number of respondents [2]

Besides, to obtain accurate conclusions, the study deployed the following data analysis method. First, it involved deductive and inductive methods, namely using a system of conclusions that were general to specific or vice versa from those specific to the public. Secondly, it also operationalized comparative method, which was by comparing one data with another data or between one theory with and theory.

\section{Result and Discussion}

The population composition in Manado City is very heterogeneous, with respect to both ethnic and religious backgrounds. The majority of the population were native from BolaangMongondow, Gorontalo, Sangihe and Talaud and Minahasa (BOHUMASI) tribes, Arab and Chinese descendants and immigrant residents such as Javanese, Makassarese, Batak, Ambonese, Padang and so on. The religions embraced by the people of Manado city are Protestant Christianity, Islam, Catholicism, Hinduism, Buddhism and Confucianism. The diversity of ethnicities and religious differences in the city can affect social interaction, which results in social changes characterized by differences in attitudes and feelings. It might give rise to competition and result in prolonged clashes and conflicts between them, both in social life and other life.

From the research findings on the association of people encompassing different ethnicities and religions and their influence on social change in the city of Manado, information was obtained from respondents who struggled in the social organizations, especially as administrators of RT or Rukun Tetangga (a cluster of houses under village government) in the city of Manado. The social activities being referred are germane to the following.

\section{A. Education}


Formal education can be interpreted as a learning experience, through which humans can gain maturity of cognition, affection and psychomotor. As such, the longer people follow the learning process, the higher levels of ability they have. In other words, those who have higher levels of formal education can think more logically and dynamically.

The respondents' education data taken randomly are as follows. First, most of the respondents had received formal education at the university level (S1). This situation was inseparable from the availability of adequate education facilities in Manado. What is more, the public awareness concerned with the importance of education was increasingly high, allowing the community wider opportunities to obtain an education.

The level of education is concerned with the formation of attitudes and ways of thinking someone, as illustrated in the results of the following frequency distributions that represent other components.

Table 1. Frequency Distribution related to the Effect of Social Organizations activities on Increasing Knowledge and Insights

\begin{tabular}{lllrr}
\hline No & Response & Category & Total & Percentage \\
\hline & & & & \\
1. & Agree & High & 32 & 53,33 \\
2. & Hardly & Moderate & 19 & 31,67 \\
3. & agree & Low & 9 & 15,00 \\
& Disagree & & & \\
& & & $\mathbf{6 0}$ & $\mathbf{1 0 0}$ \\
& & & & \\
& & & &
\end{tabular}

The table above illustrates that by actively participating in social activities is directly related to being unable to increase their knowledge and insights. The confidence of Organizational Managers in Manado City was distributed in the high category at $32(53.33 \%)$, the medium category was reported by 19 subjects $(31.67 \%)$ and low category which was also reported by 9 $(15.55 \%)$. In nature, based on observation and perception, which is something that is natural and will happen to everyone who gets natural or formed stimuli. This type of learning tends to escalate, although not always so and can be considered as a result of personal experience.

From the data in table 3, it can be seen that out of 32 subjects (53.33\%) had a high level of concern as RT Administrators who were directly seen in their activities, both through community social activities and through leadership training they had participated in. Most RT Managers in the city of Manado had attended secondary school education, making the RT Managers more open and sensitive to things that could develop their mindsets. 
Table 2. Frequency Distribution on Education AddingInsight to the Management of RT with Respect to Social Change

\begin{tabular}{lllll}
\hline No & Response & Category & Total & Percentage \\
\hline & & & & \\
1. & Agree & High & 29 & 48,33 \\
2. & Hardly & Moderate & 18 & 30,00 \\
3. & agree & Low & 13 & 21,67 \\
& Disagree & & & \\
\multicolumn{2}{l}{ TOTAL } & & $\mathbf{6 0}$ & $\mathbf{1 0 0}$ \\
\hline
\end{tabular}

Table 2 above shows that the existence of education/knowledge opens up their insights in carrying out intercultural and religious associations in the city of Manado. This finding was distributed in the high category as reported by 29 subjects (48.33\%), medium category as reported by 18 subjects $(30 \%)$ and low category as voiced by 13 subjects $(21.67 \%)$ The abovementioned data clearly indicate that formal education (ranging from elementary education to higher education) and non-formal education can generally increase knowledge and insight for those who experience the situation and reality around them, such as socializing in society and creating harmony among religious people. Therefore, they were also challenged to learn and know the teachings of religion other than what they adhered to. This study was supported by Soerahmad's opinion in Soetarno, stating that learning is a process of change within humans from not knowing to knowing [4].

The distribution of data demonstrated that the factors that influenced a person to learn included the following: 1). The objective factor, which is concerned with learning as an activity manifesting all organs in the body. In this learning process, we needed awareness or understanding of learning purposes, so that it can direct its senses and thoughts to achieve learning objective; 2). Internal factors, which affect a person's learning activities, include physical factors such as interests, gender, physical condition and psychological factors;3). External factors, that is social factors, which relate to people who live around people and non-social factors, such as aircondition, weather, place and learning equipment, and so on. The data above illustrates that 33 subjects (55\%) have knowledge and experience that can provide an understanding of new things, especially among religious adherents.

Knowledge is an element to form perceptions that involve such components as cognition and attitude. Knowledge will give meaning to an object [5]. By knowing an object, someone will know something that is related to that object well.

\section{B. Attitude}

Having an attitude that tends to understand and accept ethnic and religious diversity will lead to productive and conducive behavior. Therefore, RT Managers have the greatest opportunity in creating social change through the association of diverse ethnic and religious communities, according to the following table. 
Table 3.The Most Substantial Frequency Distribution on Opportunities for Management of RT greatest in creating Social Change through inter-ethnic and religious relations

\begin{tabular}{lcccc}
\hline No & Response & Category & Total & Percentage \\
& & & & \\
1. & Agree & High & 35 & 58,33 \\
2. & Hardly agree & Moderate & 17 & 28,33 \\
3. & Disagree & Low & 8 & 13,33 \\
& TOTAL & & $\mathbf{6 0}$ & $\mathbf{1 0 0}$ \\
& & & & \\
\hline
\end{tabular}

Table 3 above illustrates that RT administrators have the greatest opportunity in creating social change through inter-ethnic and religious relations in the city of Manado. This was distributed in the high category by 35 subjects $(58.33 \%)$, the medium category was indicated by 17 respondents $(28.33 \%)$ and the low category $8(13.33 \%)$. Based on this distribution, it meant that the care of the RT administrators addressed social change as high, because as their community leaders must have their own consequences within themselves so that they can further enhance the local resilience of the region from the threat of social change that tends to be destructive through inter-ethnic activities and social cooperation and religious communities.

Table 4. Distribution of Frequency of Involvement of Administrators $R T$ Operative to Create social change

\begin{tabular}{lllrc}
\hline No & Response & Category & Total & Percentage \\
\hline & & & & \\
1. & Agree & High & 32 & 53,33 \\
2. & Hardly agree & Moderate & 19 & 31,67 \\
3. & Disagree & Low & 8 & 13,33 \\
\multicolumn{2}{l}{ TOTAL } & & $\mathbf{6 0}$ & $\mathbf{1 0 0}$ \\
\hline
\end{tabular}

Table 4 above illustrates that the involvement of administrators of RT can influence the occurrence of social change through the association of diverse ethnic and religious communities.This is distributed in the high category by 32 subjects $(53.33 \%)$, medium category as marked by 19 respondents (31.67\%) and low category manifested by 8 respondents (13.33\%) Based on the data in table 2, it is clear that $32(53.33 \%)$ respondents have a positive attitude acknowledging the influence of RT management in social change in the city of Manado.

Social change is connected through individual actors. One theory related to social change is the theory of conflict. The main concern for conflict theory is knowing and analyzing the presence 
of conflict and social life because in its form and in many ways the consequences in causing social change.

Table 5. Frequency Distribution on Social Organizations Public Relations Actualized in the Role and involvement of RT administrators in their association.

\begin{tabular}{ccccc}
\hline No & Response & Category & Total & Percentage \\
& & & & \\
1. & Agree & High & 29 & 48,33 \\
2. & Hardly agree & Moderate & 17 & 28,33 \\
3. & Disagree & Low & 14 & 23,33 \\
& TOTAL & & $\mathbf{6 0}$ & $\mathbf{1 0 0}$ \\
& & & & \\
\hline
\end{tabular}

Table 5 above illustrates that the Community Social Organization can be a measure and description of the role and involvement of RT management in their associations. The image is distributed in the high category including 29 subjects $(48.33 \%)$, the medium category marked by 17 people $(28.33 \%)$ and the low category characterized by 14 respondents $(23.33 \%)$. To be able to distinguish between attitudes and other psychological factors, RT management must also take into account the characteristics of attitude.

According to Gerungan, attitude characteristics are as follows:

1. Attitudes are not obtained from birth, but are formed or studied as long as the person's development in relation to the object.

2. Attitudes can change, because attitude can be learned by people.

3. Attitudes do not stand alone, but are always in tandem with an object.

4. Object attitude can be a certain thing, but can also be a collection of a series of objects.

5. Attitudes have modification aspects and aspects of feeling. [6]

Furthermore, according to Effendi, attitude characteristics are as follows:

The attitude factor is not inherent from birth, but is formed during its development as a result of its relationship with objects in its environment.

1. Attitudes can change as a result of interaction between someone and other people.

2. Attitudes do not stand alone, but always contain relations with an object. The object is not just one type, but varies according to the number of objects that concern the person concerned.

3. Attitudes are related to the dimension of time, which means that the attitude is only suitable for situations at a certain time. Therefore attitude can change according to the situation.

4. Attitudes do not disappear even though the needs have been fulfilled.

5. Attitudes contain motivational and emotional factors. [7]

Based on the characteristics mentioned above, attitude can be a view, but in this case, it is still different from a person's knowledge. Knowledge of an object is not the same as the attitude towards the object. Knowledge of a new object becomes an attitude towards an object if that knowledge is accompanied by a readiness to act according to the knowledge of the object itself. 


\section{Social Interaction}

Humans are basically social beings, as they have an instinct for living with other humans. Human instincts to live with other people are called gregariousness, so humans are also referred to as social animals [8]. This arena since the birth of man has two desires or desires, namely: the desire to become one with other human beings around him, or society, another one is the desire to unite with the surrounding atmosphere [9]. To establish a good relationship between humans, religion is a very important element in it. One function of religion is to foster a sense of brotherhood [10]. In social interactions, there is communication that involves stimuli and responses or certain responses that cause people or individuals to influence each other. This process can take place between individuals, between groups, and individuals with groups as well as vice versa, as is indirectly implied in the opinion of Gerungan, pointing out that communication is the relationship of two or more individual humans in which the behavior of individuals affects, changes or improves the behavior of other individuals or vice versa [7].

The social environment is a community environment, wherein that environment there is one individual interaction with another individual. This opinion focuses more on interactions within the community. This can be understood because the community environment has more influence on social change. This present study on the environment in question is the family environment, community environment and the environment of social organizations. An environment involves the interaction between individuals, individuals and groups acquiring certain kinds of knowledge. The degree of intensity of interaction with this social environment will not be separated from the extent of the narrow thinking horizon determined by the level of formal education that has been achieved by someone.

Important information obtained in this study is a matter of interaction between ethnic and religious groups. Interaction can be done through direct meetings, through news and also through face-to-face meetings. Interaction with other ethnic groups and religions is the basis for knowing that other ethnic groups and religions exist and hence certain impressions can be obtained.

The difference in multicultural background triggering such conflicts requires communication to form a common and effective social interaction. Therefore, the level of mutual understanding between ethnic groups or between groups can be created. Stereotypes, prejudices, and discrimination often lead to racial hatred and unrest. In Indonesia, this applies to not only Chinese society only, but also other ethnic groups, such as Batak, Minangkabau, Javanese, Sundanese, Madurese, and Dayaks. This can happen if the ethnic groups live in an area where they dominate the environment. Judging from the socio-historical angle, the weight of each case varies [11].

Interaction between ethnic groups, religions in daily life is peaceful, more intimate and more frequent. This is because the internal religious community is classified as orderly so that it becomes the basis for wider interaction in the city of Manado. 
Table 6. Frequency Distribution on Inter-Religious Interaction as a foundation in conducting social interactions

\begin{tabular}{lllrc}
\hline No & Response & Category & Total & Percentage \\
\hline & & & & \\
1. & Agree & High & 39 & 65,00 \\
2. & Hardly & Moderate & 14 & 23,33 \\
$3 . \quad$ & agree & Low & 7 & 11,67 \\
& Disagree & & & \\
\multicolumn{7}{l}{ TOTAL } & & $\mathbf{6 0}$ & $\mathbf{1 0 0}$ \\
\hline
\end{tabular}

Table 6 above illustrates that the internal interaction of religious people is the foundation of interaction in society in general. This finding is distributed in the high category voiced by 39 subjects $(65 \%)$, medium category as reported by 14 subjects $(23.33 \%)$, and low category reported by 7 respondents (11.67\%) Meanwhile, inter-religious and ethnic interaction in daily life is peaceful, more intimate and more frequent.This is because the internal association of religious and ethnic groups is classified as orderly so that it becomes the basis for wider social interaction.

Relations between residents in Manado City from various religions and tribes in the face of adherents and the community tend to be conducive. However, this does not guarantee that in different environments occur only a little offense and suspicion even though it does not lead to personal and group conflicts. As a corollary, the friendship between religious and ethnic groups different has taken place.

According to Blumer, interaction rests on three premises:

First, humans act on something based on the meanings relevant to them. Second, the meaning comes from someone's social interaction with others. Third, these meanings are perfected when the process of social interaction takes place [12].

The meanings referred to here are things related to social change practiced by the community through the process of social interaction.

Table 7. Distribution of Frequencies on Inter-ethnic and Religious Group Activities Strengthening Brotherhood and Fostering Mutual Understanding and Correct Understanding

\begin{tabular}{lllrc}
\hline No & Response & Category & Total & Percentage \\
\hline & & & & \\
1. & Agree & High & 39 & 65,00 \\
2. & Hardly & Moderate & 14 & 23,33 \\
3. & agree & Low & 7 & 11,67 \\
& Disagree & & & \\
\multicolumn{2}{l}{ TOTAL } & & 60 & 100 \\
\hline
\end{tabular}


Table 7 above illustrates that activities between ethnic groups and religions can strengthen brotherhood and foster mutual understanding and correct understanding of other ethnic and religious differences with it. The influence is distributed in the high category reported by 39 subjects $(65 \%)$, medium category as marked by 14 subjects ( $23.33 \%$ ) and low category indicated by 7 respondents $(11.67 \%)$.

Based on the data distribution, RT administrators have a fairly vital role in creating a conducive atmosphere in facing and responding to social changes in the city of Manado with intensive social interaction between the people. Hopefully, there will be a common understanding and view that between social interactions between ethnic groups, and religions, in turn, will encourage them to increase their activities in the field of inter-ethnic and religious cooperation. Such cooperation is believed to ultimately have a positive impact on people's lives in Manado City in general.

\section{Conclusion}

Based on the research findings, it can be concluded that the interaction between ethnicities and religions has a positive and significant effect on social change in the city of Manado. This is owing to a number of factors. These include the following.

1. Education, both formal and non-formal education;

2. Attitudes, namely openness and mutual understanding in accepting and responding to ethnic and religious diversity;

Social interaction, good and harmonious relations between different ethnic and religious groups of society with family, environment/community and fellow administrators of the Neighborhood Association.

\section{References}

[1] Departemen Agama RI, Al-qur'an dan terjemahannya. Bogor: PT Karya Azzahra Mandiri, 2014.

[2] M. Nazir, Metode Penelitian Sosial. Jakarta: Ghalia Indonesia, 1988.

[3] S. Zainal, "Konflik Sosial Keagamaan Islam Non-Mainstream Dalam Masyarakat Majemuk Di Indonesia," J. Al- Ulum, vol. 12, no. 2, p. 243, 2012.

[4] M. Nazir, Metode Penelitian Sosial cc. Jakarta: Ghalia Indonesia, 1988.

[5] R. Soetarno, Psikologi Sosial. Jakarta: Yayasan Kanisiun, 1994.

[6] Mar'at, Sikap Manusia, Perubahan Sosial dan Pengukurannya. Jakarta: Ghalia Indonesia, 1984.

[7] W. A. Gerungan, Psikologi Sisial. Bandung: Eresco, 1996.

[8] W. A. Gerungan, Psikologi Sisialcc. Bandung: Eresco, 1996.

[9] S. Soejono, Pengantar Sosiologi. Jakarta: PT Raja Grafindo, 1982.

[10] Khotimah, "Interaksi social Masyarakat Islam dan Kristen di Dusun IV Tarab Mulia Kecamatan Tambang Kabupaten Kampar," KutubkhanahJurnal Penelit. Sos. keagamaan, vol. 19 , no. 2, p. 242, 2016. 
[11] J. Christiany, "Stereotip dan Prasangka dalam Konflik Etnis Tionghoa dan Bugis Makassar," J. Ilmu Komun., vol. 12, no. 1, pp. 87-104, 2015.

[12] O. U. Effendi, Psikologi Komunikasi. Bandung: Tarsito, 1988. 